\title{
Decolourization of Textile Dye Effluent by Non-Viable Biomass of Aspergillus fumigatus
}

\author{
K. Kalaiarasi ", A. Lavanya, S. Amsamani and G. Bagyalakshmi \\ Department of Textiles and Clothing; Avinashilingam University for Women; Coimbatore - 641 043; Tamil Nadu - \\ India
}

\begin{abstract}
The aim of this work was to study the decolourization of textile dye effluent by non-viable biomass of Aspergillus fumigates. The dried non-viable fungal biomass exhibited maximum dye removal at $\mathrm{pH} 7.0$ with temperature of $30^{\circ} \mathrm{C}$ and $3 \mathrm{~g} / \mathrm{l}(\mathrm{w} / \mathrm{v})$ biomass concentration, after $24 \mathrm{~h}$ contact time. The results showed that the non-viable biomass possessed high efficiency for dye removal from textile effluent.
\end{abstract}

Key words: Aspergillus fumigatus, decolourization, textile effluent

\section{INTRODUCTION}

Contamination of water sources by many organic pollutants is a major factor of global environmental pollution for number of years (Akthar et al. 2006). Two major sources of dye pollution are the textile and dye stuff manufacturing industries. Effluents of these industries are highly colored and very difficult to treat since the dyes used are synthetic complex molecules that are resistant to aerobic digestion and stable to light, heat and oxidizing agents $(\mathrm{Fu}$ and Viraraghavan 2001; Radha et al. 2005; Crini 2006).

Worldwide over 10,000 different dyes and pigments are used in dyeing and printing industries. The total world colorant production is estimated to be $8,00,000$ tons per year and at least $10 \%$ of the used dyestuff enters the environment through waste (Levin et al. 2004; Palmieri et al. 2005). It is estimated that 2,80,000 tons of textile dyes are discharged in such industrial effluents every year worldwide (Maas and Chudhari
2005).Improper textile dye effluent disposal in aqueous ecosystems leads to the reduction in sunlight penetration which in turn decreases the photosynthetic activity, dissolved oxygen concentration, water quality and depicts acute toxic effects on aquatic flora and fauna, causing severe environmental problems world-wide (Vandevivere et al. 1998). Hence, treatment of such dye containing waste water is essential to prevent the deterioration of ecosystem.

Several physicochemical methods such as absorption, membrane filtration, photo catalytic degradation, ion exchange, precipitation, flocculation, floatation and ozonation are quite effective in decolorization of dyes, have some disadvantages such as high cost / unit volume of waste water treated, unfriendly for nature or unreliability in operation (Aksu 2005). Therefore, there is a need to develop alternative and cost effective treatment process for colored effluents. The microbial decolourization and degradation has been of considerable interest since it is

*Author for correspondence: kalaiarasik@ rediffmail.com 
inexpensive, eco-friendly and produces a less amount of sludge (Kalyani et al. 2008).

Both living and dead biomass can be used to remove the hazardous organics. Dead cells are obviously preferable for waste water treatment since they are not affected by toxic waste and chemicals and do not pollute the environment by releasing toxins (Aksu 2005).They also do not require a continuous supply of nutrients and can be regenerated and reused for many cycles (Sumathi and Manju 2000; Volesky 2001; O'Mahony et al. 2002; Aksu 2005; Maurya et al. 2006; Vijayaraghavan and Yun 2006; Won et al. 2006).

Dead and dried biomass can be stored for longer periods at room temperature with little risk of putrefaction. This makes it easier to use and transport. Dead biomass is also generated as a waste product from established industrial process (Kapoor and Viraraghavan 1998).

Rhizopus arrhizus (Aksu and Cagatay 2006), Aspergillus niger (Fu and Viraraghavan 2002), Neurospora crassa (Akar et al. 2006) Penicillum chrysosporium (Radha et al. 2005) and Aspergillus fumigatus (Wang et al. 2008) are some of low cost fungal materials which have been used as biosorbent for dyes. Hence, in present study, the feasibility of using dead biomass of $A$. fumigatus for colour removal from textile dye effluent was examined.

\section{MATERIALS AND METHODS}

\section{Collection of samples}

Textile effluent containing reactive dye and soil contaminated with textile dye effluent were collected from a dyeing unit in a sterile polythene container following Manivasagam (1995) and stored at $4^{\circ} \mathrm{C}$ until analysis was done.

\section{Screening, isolation and identification of textile dye effluent decolorizing fungi}

One gram of soil sample was mixed with $10 \mathrm{ml}$ of distilled water and serial dilution was made up to $10^{-9}$ on potato dextrose agar to isolate the fungal strains. The well-grown fungal colonies were screened for their dye decolorizing effect by inoculating them in $100 \mathrm{ml}$ of textile dye effluent in $250 \mathrm{ml}$ Erlenmeyer flask. Per cent decolorization was determined by measuring the absorbance of the effluent at $290 \mathrm{~nm}$ in UVvisible spectrophotometer. The fungal strain which showed maximum decolorization percentage was selected for the present study. The selected fungal isolate was identified by lacto phenol cotton blue staining method.

\section{Preparation of dead biomass of $\boldsymbol{A}$. fumigatus}

The mat formed by $A$. fumigatus grown in Sabaroud dextrose broth was separated by filtration, autoclaved and washed with distilled water to remove the colour and impurities and dried in an oven. The dried biomass was powdered (Engade and Gupta, 2007).

\section{Optimization for decolorization}

Effect of different concentrations of dead biomass

One hundred milliliter of textile dye effluent was taken in $250 \mathrm{ml}$ Erlenmeyer flasks. The flasks were added with various concentrations of dried and powdered biomass such as 0.2, 0.4, 0.6, 0.8, 1.0, 1.2 and $1.4 \%(\mathrm{w} / \mathrm{v})$ and incubated at $28^{\circ} \mathrm{C}$ for five days. After incubation period, per cent decolorization was determined.

\section{Effect of incubation period}

To determine the impact of incubation period on decolorization, $0.6 \mathrm{~g}$ of dead biomass of $A$. fumigatus was added to $100 \mathrm{ml}$ of textile dye effluent. The flasks were incubated at different time intervals such as 24, 48, 72, 96 and $120 \mathrm{~h}$. After each incubation period, per cent decolorization was calculated.

\section{Effect of $p H$}

To determine the optimum $\mathrm{pH}$ for decolorization, the $\mathrm{pH}$ of the effluent was adjusted to 5.0-9.0 at an interval of one unit using $1 \mathrm{~N} \mathrm{Hcl}$ and $1 \mathrm{~N} \mathrm{NaOH}$ and per cent decolorization was calculated.

\section{Effect of temperature}

The inoculated flasks were incubated at different temperatures such as $20,30,40,50,60,70$ and $80^{\circ}$ $\mathrm{C}$ for $24 \mathrm{~h}$. After the incubation period, percent decolorization was calculated.

\section{RESULTS AND DISCUSSION}

Screening, isolation and identification of textile dye effluent decolorizing fungi

Seven morphologically distinct fungi were isolated from the textile dye effluent contaminated soil by serial dilution technique. Among them, the fungal 
isolate which showed highest per cent decolorization (Table 1) was selected.

Based on the colony morphology and staining, the fungal strain was identified as Aspergillus fumigatus. Mature colonies were yellow brown in texture and the surface was powdery or granular and the hyphae were septate in nature. The conidial head was columnar and compact, the conidiophores appeared green and sterigma was uniseriate in nature.

Table 1 - Decolourization of textile dye effluent by different fungal strains.

\begin{tabular}{lc}
\hline Fungal isolates & Rate of decolourization ( \%) \\
\hline Rhizopus sp. & 25 \\
Penicillium sp. & 30 \\
Cladosporium sp. & 35 \\
Aspergillus sp. & $\mathbf{6 7}$ \\
Trichoderma sp. & 39 \\
Fusarium sp. & 23 \\
Flavodon sp. & 15 \\
\hline
\end{tabular}

\section{Optimization for decolorization} Effect of different concentrations of dead biomass

Maximum decolorization was observed at $0.6 \%$ $(\mathrm{w} / \mathrm{v})$ of biomass concentration (Fig 1.). It is widely known that the number of available biosorption sites increase with an increase in biosorbent concentration. Further increment in biomass concentration above $0.6 \%$ did not improve biosorption. This was due to the fact that almost all the ions were bound to the biomass at the establishment of equilibrium between the dye molecules bound to the biomass and those remaining un-adsorbed in the solution (Vasanthkumar et al. 2006).

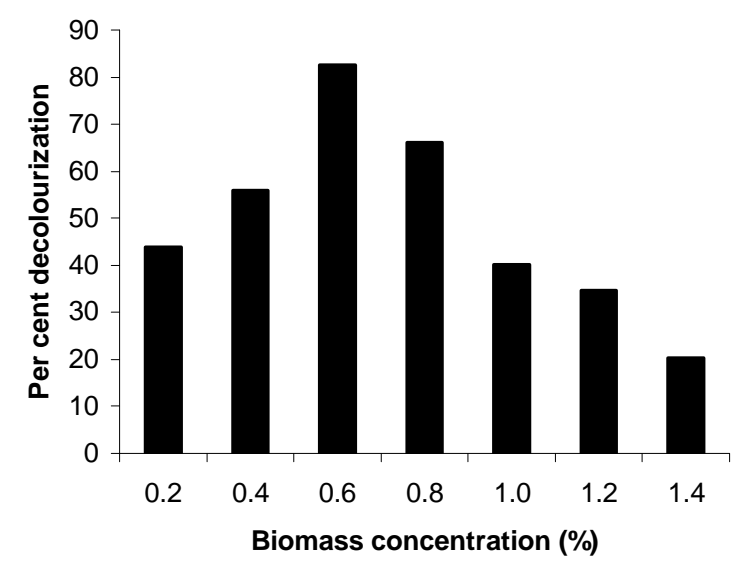

Figure 1 - Effect of non-viable biomass concentration of A. fumigatus on decolourization.

\section{Effect of incubation period}

Maximum decolourization was observed at $48 \mathrm{~h}$ of incubation (Fig. 2). However, Prigione et al. (2008) reported maximum decolourization at $24 \mathrm{~h}$ of incubation by autoclaved biomass of three mucorales fungi of C.elegans, $R$. pusillus and $R$. stolonifer. 


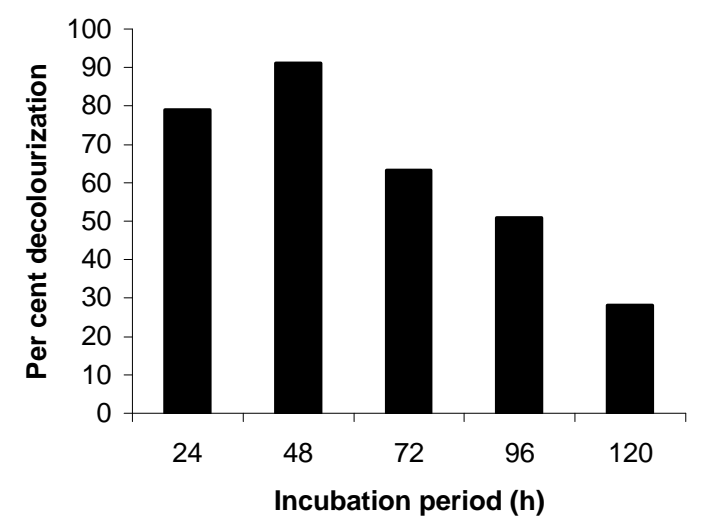

Figure 2 - Effect of incubation period on decolourization by dead biomass of A.fumigatus.

\section{Effect of $p H$}

Per cent decolourization was increased with increase in $\mathrm{pH}$ and reached maximum at $\mathrm{pH} 7.0$ (Fig. 3). Above this pH 7.0, there was a decline in per cent decolorization. The result was in accordance with Yatome et al, (1991) for decolourization of triphenylmethane dyes by
Pseudomonas pseudomallei. Similarly, Kwasniewsaka (1985) found that Rhodotorula sp. decolorized crystal violet maximum at $\mathrm{pH}$ 7.0. However, Wang et al. (2008) reported that the optimum $\mathrm{pH}$ for biosorption of azo dye by $A$. fumigatus was 2.0.

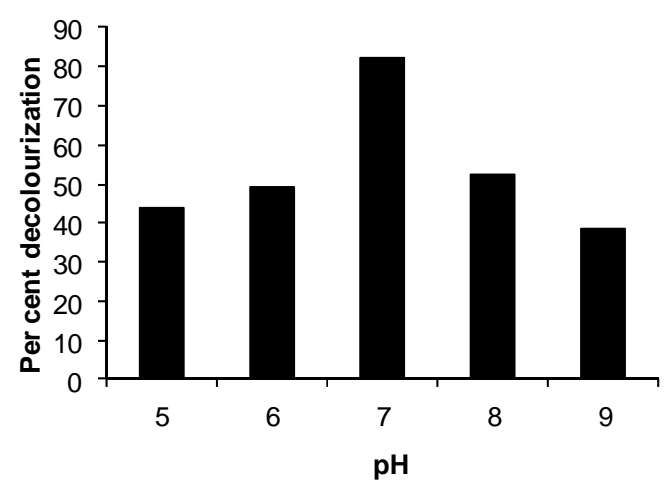

Figure 3 - Effect of $\mathrm{pH}$ on decolourization by dead biomass of A.fumigatus.

\section{Effect of temperature}

The optimum temperature for decolourization was $30^{\circ} \mathrm{C}$ (Fig. 4). Increase in temperature above this resulted in decrease in per cent decolourization. Similar trend was observed by Khalaf (2008) for biosorption of reactive dye from textile dye effluent by non-viable biomass of A.niger and Spirogyra sp. Increase in temperature above $30^{\circ} \mathrm{C}$ may alter the surface activity of biomass which results in a decrease in removal value, indicating that this process is exothermic in nature. The exothermic nature of dye biosorption has also been reported for the biosorption of Ramazol Black B and Acid Red 274 dyes by Rhizopus airhizus and E. prolifer, respectively. (O'Mahony et al. 2002; Ozer et al. 2005). A similar observation has been reported for ramazol brilliant blue on eucalyptus bark, where adsorption decreased at higher temperatures; similar trend was observed for comparative studies on removal of Congo red by native and modified mycelial pellets of Trametes versicolor in various reactive modes (Binupriya et al. 2008). 


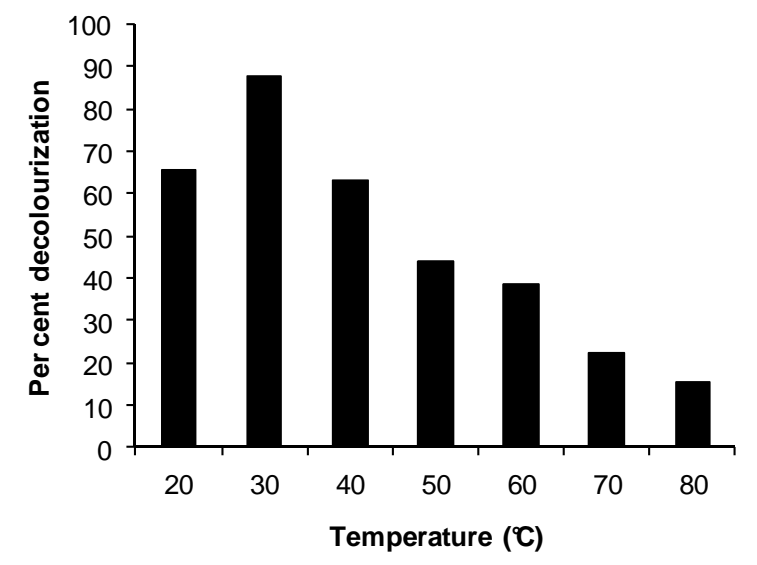

Figure 4 - Effect of temperature on decolourization by dead biomass of A.fumigatus.

\section{CONCLUSIONS}

The present study revealed the ability of the dead biomass of $A$. fumigatus to remove the reactive dye from textile dye effluent. The results obtained from this work showed that the fungal biomass possessed high decolourization efficiency. The findings offer potential for the development of a cost effective and robust technology for biosorption of reactive dye effluents.

\section{REFERENCES}

Akar TA, Kiran I, Ozcan AS, Tunali S. Biosorption potential of neurospora crassa cells for decolorization of acid red 57 (AR57) dye. J Chem Technol Biotechnol. 2006; 81:1100-1106.

Akthar M, Bhanger MI, Iqbal S, Hazang SM. Biosorption potential of rice husk for the removal of 2,4-dichlorophenol from aquoes solutions. Kinetics and thermodynamic investigations. $J$ Hazard Mater. 2006; 128: 44-52.

Aksu Z. Application of Biosorption for the removal of organic pollutants - A Review. Process Biochem. 2005; 40: 997 - 1026.

Aksu Z, Cagatay SS. Investigation of biosorption of gemasol turquise blue-G reactive dye by dried Rhizopus arrhizus in batch and continuous systems. Sept Purif Technol. 2006; 48: 24-35.

Binupriya AR, Sathishkumar M, Swaminathan K, Ku CS, Yun SE. Comparative Studies on removal of Congo Red by native and modified mycelias pellets of Trametes versicolor in various reactor modes. Bioresour Technol. 2008; 99: 1080 - 88.
Crini G. Non conventional low cost adsorbents for dye removal; a review. Bioresour Technol. 2006; 97: 95371.

Engade A, Gupta B. Dead fungal biomass of Aspergillus niger. Pollution Res. 2007; 53: 51-53.

Fu Y, Viraraghavan T. Fungal decolorization of dye waste water - a Review. Bioresour Technol. 2001; $82: 139-145$.

$\mathrm{Fu} \mathrm{Y}$, Viraraghavan T. Dye biosorption sites in Aspergillus niger. Bioresour Technol. 2002; 83: 139 $-145$.

Kalyani DC, Patil PS, Jadhav JP, Govindwar SP. Biodegradation of reactive textile dye red BLI by an isolated bacterium Pseudomonas sp. SUK1. Bioresour Technol. 2008; 99: 4635-4641.

Kapoor A, Viraraghavan T. Heavy metal biosorption sites in Aspergillus niger. Bioresour Technol. 1998; 61: $221-7$.

Khalaf MA. Biosorption of reactive dye from textile waste water by non-viable biomass of Aspergillus niger and Spirogyra sp. Bioresour Technol. 2008; 99: $6631-4$.

Kwasniewsaka K. Biodegradaion of Gentian Violet by red oxidative yeasts. Bull Environ Contam Toxicol. 1985; 34: 323 - 333.

Levin L, Papinatti L, Forchiassin F. Evaluation of Argentinean white rot fungi for their ability to produce lignin-modifying enzymes and decolorize industrial dyes. Bioresour Technol. 2004; 94:169-176.

Maas R, Chudhari S. Adsorption and biological decolorization of azo dye reactive red 2 in semi continuous anaerobic reactors. Process Biochem. 2005; 40: 699-705.

Manivasagam A. Treatment of textile processing effluent. Coimbatore, India, Sakthi Publications, 1995. 
Maurya NS, Mittal AK, Cornelp A, Rother E. Biosorption of dyes using dead macrofungi. Effect of dye structure ionic strength and $\mathrm{pH}$. Bioresour Technol. 2006; 97: $512-521$.

O'Mahony T, Guibal E, Tobin JM. Reductive dye biosorption by Rhizopus asrhizus biomass. Enzyme Microb Technol. 2002; 31: 456 - 463.

Ozer A, Akkaya G, Turabik M. Biosorption of Acid Red 274 (AR274) on Enteromorpha prolifera in a batch system. J Hazard Matter. 2005; 126: 119 - 127.

Palmieri G, Cennamo G, Sannia G. Rama 201 Brilliant $\mathrm{R}$ decolorization by the fungus Pleurotus ostreatus and its oxidative enzymatic system. Enzyme Microb Technol. 2005; 36:17-27.

Prigione V, Varese GL, Casiseri L, Marchision VF. Biosorption of simulated dye effluents by inactivated fungal biomasses. Bioresour Technol. 2008; 99: 3539 -3567 .

Radha KV, Arunagiri A, Murugesan T. Decolourization studies of synthetic dyes using Phanearocheate chrysosporium and their kinetics. Process Biochem. 2005; 40: 3337-3345.

Sumathi S, Manju BS. Uptake of reactive textile dyes by Aspergillus toetidus. Enzyme Microb Technol. 2000; 27: 347 - 355 .

Vandevivere PC, Bianchi R, Verstraete W. Treatment and reuse of wastewater from the textile wetprocessing industry: review of emerging technologies. J Chem Technol Biotechnol. 1998; 72: 289-302.

Vasanthkumar K, Ramamurthy V, Sivanesan S. Biosorption of Malachite Green, a cationic dye on to Pithophor sp. a fresh water algae. Dyes Pigments. 2006; 69:102-7.
Vijayaraghavan K, Yun YS. Utilization of fermentation waste (Corynebouterium glutamicum) for biosorption of reactive blacks from aqueous solutions. $J$ Hazard Matter. 2006; 141: 45 - 52.

Volesky B. Detoxification of metal bearing effluents: Biosorption for the next century. Hydrometallurgy. 2001; 59: $203-216$.

Wang BE, Hu YY, Xie L, Peng K. Biosorption behaviour of azo dye by inactive CMC immobilized A.fumugatus beads. Bioresour Technol. 2008; 99: 794-800.

Won SW, Kim HJ, Choi SH, Chung BW, Kim KJ, Yun YS. Performance, kinetics and equilibrium in biosorption of Anionic Dye Reactive Blacks by the waste biomass of Corynbacterium glutamicum as a low - cost biosorbent. Chem Engg J. 2006; 121: 37 43.

Yatome L, Ogawa T, Matsui M. Degradation of Gentian Violet by Bacillus subtilis. J Environ Sci Hlt. 1991; 26: $75-87$. 